\title{
The Utilization of Natural Materials in Improving Children's Intelligence
}

\author{
$1^{\text {st }}$ Eneng Sri Susilawati \\ STKIP Setiabudhi Rangkasbitung \\ Indonesia \\ $4^{\text {th }}$ Ayu Fajarwati \\ STKIP Setiabudhi Rangkasbitung \\ Indonesia
}

\author{
$2^{\text {nd }}$ Eka Setiawati \\ STKIP Setiabudhi Rangkasbitung \\ Indonesia \\ echasetia14@gmail.com \\ $5^{\text {th }}$ Yusdiana \\ STKIP Setiabudhi Rangkasbitung \\ Indonesia
}

\author{
$3^{\text {rd }}$ Elih Solihatulmilah \\ STKIP Setiabudhi Rangkasbitung \\ Indonesia \\ $6^{\text {th }}$ Yadi Heryadi \\ STKIP Setiabudhi Rangkasbitung \\ Indonesia
}

\begin{abstract}
The objective of this study is to improve the Naturalist intelligence of students. The research technique used was Classroom Action Research conducted with the aim to improve the quality of learning practice in the classroom. The source of data of this study is children aged 5-6 years in group $B$, the researcher, collaborator, and the principal of An-Nisa Playgroup. The results of the research show that learning through the use of Natural Materials can enhance the ability of children's ability of Naturalist intelligence at An-Nisa Playgroup in Petir District, Serang Regency. The success rate of this research is very significant. On preliminary study, we obtained an average percentage of $\mathbf{3 6 . 3 7 \%}$ that increased to $57.57 \%$ in Cycle I and increased to $94.96 \%$ in Cycle II.
\end{abstract}

Keywords-Utilization, Natural Materials, Childrens, Intellegence

\section{INTRODUCTION}

A child's intelligence not only can be measured from the intellectual capacity. A child is said to be intelligent if he/she can show one or two abilities that became his superiority[1]. Naturalist intelligence in children aged 4-6 years can be seen when they have started to have a sense of sensitivity to the environment, they already have an interest in nature (by observing, involved, looking at the images, collecting elements plants/animals), care for and nurture animals/plants, documenting through images, and search for information through asking, viewing, and reading[2]. To develop the naturalist intelligence of children can be done with activities through the utilization of natural materials. The utilization of natural materials has a significant influence on the development of children's naturalist intelligence. Through the utilization of this material, the child will become more creative to create the tools of the game by using items, objects, or plants in the surrounding environment so it can get students closer and being the part of nature.

\section{THEORETICAL FRAMEWORK}

\section{A. Naturalist Intelligence}

According to Gardner in Yuliani [1]Naturalist Intelligence is the skill to recognize and categorize species (flora, fauna) in the surrounding environment, recognize the existence of a species, map the relationship between the species. This intelligence includes sensitivity to other natural phenomena (e.g. cloud formations and mountains). The other components of the naturalist intelligence are the attention and deep interest in the nature, as well as the accuracy in finding the traits of the species and other elements of nature. For those who live in the big city, the ability of naturalist intelligence will appear in the form of the ability to distinguish abiotic objects like a car, rubber boots, and $\mathrm{CD}$ cover[3]. According to the In [2] the children who have high naturalist intelligence tend not to be afraid of holding insects and near the zoo, most of the children try to fulfill their curiosity by exploring the nature, they look for worms in the trash, unload the hive of the ants, and trace the river.The characteristics of children who have naturalist intelligence, as follows[2]:

- Tend to like the nature, familiar with pets.

- Spend their time near the aquarium.

- Have a great curiosity about the intricacies of animals and plants.

- Tend to like to collect the flowers and dry leaves.

- Collect toy animal replicas, such as dinosaurs, tigers, and snakes.

- Enjoy communicating with the animals and feed them.Have relatively high attention to animals, plants, and nature. They are not afraid of holding the insect and be near animals

B. The Development of Children Age 5-6 years

The naturalistic development of children is affected by the stimulus provided by the environment to them. Children aged 4-5 years have had an interest in pets. They 
also have known the parts of plant, especially the leaves, stems and flowers. Children love to investigate the various life of small creatures like worms, ants, and caterpillars. Children love to observe the earth mound, check out the traces of the animals, scrape land, observe the animals hiding and then capture and stick them to know the contents of their stomach. Children who have high naturalist intelligence tend to like nature, familiar with pets, and also spend their time near the aquarium. They have a great curiosity about the intricacies of animals and plants[3]. Children with high naturalist intelligence tend not to be afraid of holding animals and feel happy to be near the animals. Naturalist intelligence in early childhood is characterized by the skill to distinguish members of a species, recognize the existence of other species and map the relationships between some of the species, both formally and informally. The one who has an optimal natural intelligence tends to like and effective in analyzing the similarities and differences, like plants and animals, classifying flora and fauna, preserve the environment and understand its dependence on environment.

\section{Natural Materials}

Natural materials include stems, twigs, wood, leaves, rocks, grains, sand, mud and water. The child will recognize objects or materials around them indirectly such as sand, soil, corn husk, seeds of spruce, brick, variety of grass, plants and flowers that are real. Children can interact with nature through hymns of nature and walk through the park and trees. A lot of things can be introduced to children about the natural world [4].

The natural materials used are very diverse and the use of which is to be expected precisely in accordance with the state of the environment around the children. There are many steps used to utilize natural materials. The steps to use natural materials are done by classifying nature material based on the type, color, size and shape. Subsequently matched that look the same such as size or color. The advantage of using this nature material is the cost will be cheaper, even no cost at all. Also, the needed materials are easily obtained

D. The Impact of Utilizing Natural Materials toward The Naturalist Intelligence

The use of natural materials will affect the child's knowledge and the expression of their ideas. The materials can also be used for more than one theme or activity that they will be used in a variety of learning activities. Utilizing natural materials will stimulate the talent and potential of the children. Rich natural environment will develop a child's potential due to: (1) Nature is universal and renewable, (2) Nature cannot be predicted, (3) Nature is very abundant, (4) Nature is beautiful, (5) Nature creates many places, (6) Nature can heal and contains a wealth of nutritious food [5]

The utilization of natural materials supports children's learning, stimulate the imagination, easy to remember meaningful experiences and build communication[6] Also, bringing children on nature would develop the naturalist intelligence of the children and they will attach to nature. Nature provides many things that can be learned. For example, children can directly learn about the plants, animals, soil, stone, and so on

\section{RESEARCH METHODOLOGY}

The research method used is classroom action research conducted in An-nisa Playgroup in Petir District. The activity model used is the one designed by Kemmis and Taggart [7]

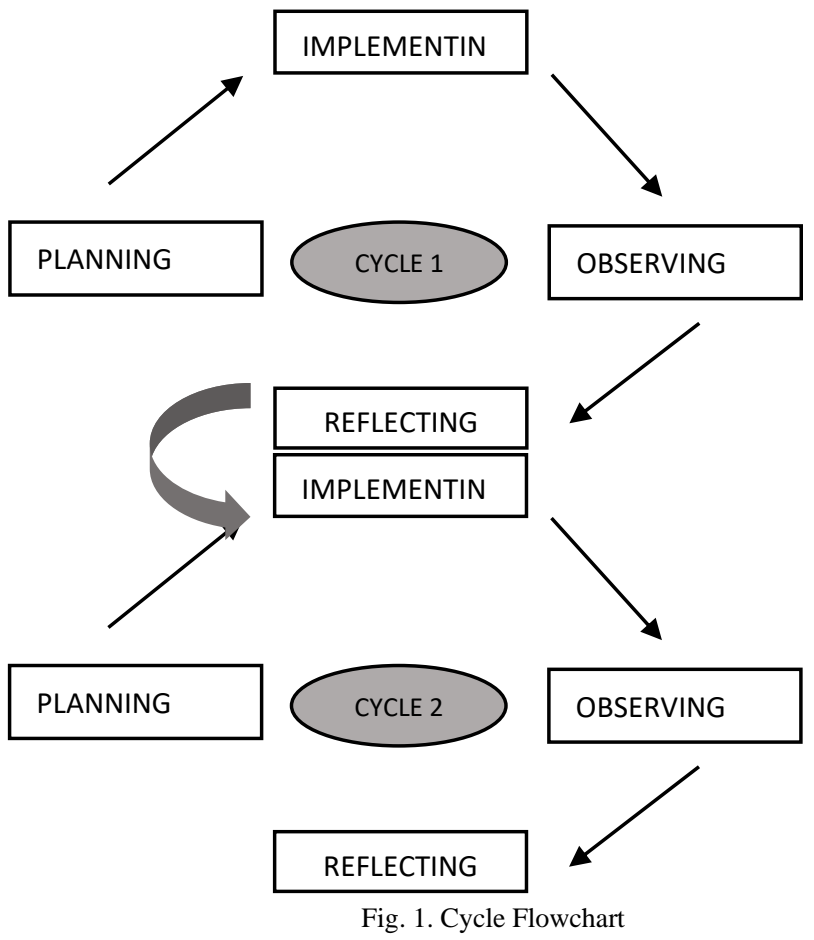


TABLE I. INSTRUMENT TO IMPROVE NATURALIST INTELLIGENCE THROUGH THE UTILIZATION OF NATURAL MATERIALS Based On Permendikbud No. 146 Of 2014 [8]

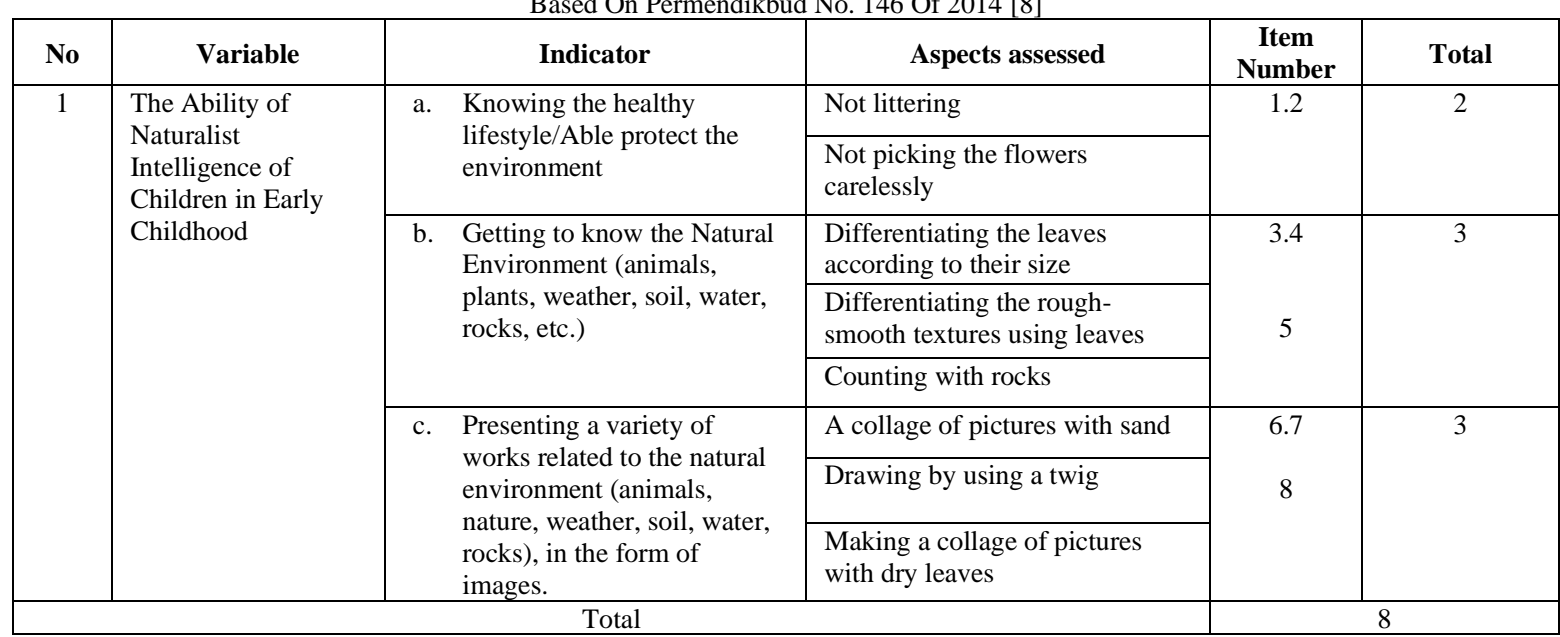

IV. RESULTS AND DISCUSSIONS

Based on the results of the data analysis by identifying the percentage of increase in the ability of naturalist intelligence both in the preliminary study and at the end of the cycle I that were $37,37 \%$ and $57.57 \%$, and the percentage of increase in the naturalist intelligence on cycle II was $46,96 \%$. These results show that in cycle I, the results of the expected improvement was not significant, then after proceeding to the second cycle, the result of the ability of naturalist intelligence had increased as expected. These results show conformity with the hypothesis of action that the percentage of increase is by $15 \%$, therefore, the hypothesis is accepted. Thus, it can be said that learning through the use of natural materials can enhance the children's ability of naturalist intelligence.

The results of the qualitative data proved that the provision of learning activities using the utilization of natural materials can enhance the ability of naturalist intelligence. The use of natural materials can improve the ability of naturalist intelligence. These can be seen in the children's learning, where they are able to make a collage from sand, the children are able to create an image from the twig, and the children are able to distinguish rough and smooth with the use of leaves. The implementation of activities with the utilization of natural materials is one of the activity presentations that encompass the fun activities for children to improve the children's ability of naturalist intelligence. Learning activities using natural materials not only develops the cognitive ability of children but also can develop other aspects. Besides their benefits, the learning activities using natural materials also have some drawbacks. For example, children have not been focused on learning activities yet.

On the preliminary research, the main score obtained was low. The child was not yet able to make a collage from sand, the child is not yet able to draw with twig. Based on those data, researchers and collaborator arranged the learning process to perform the action in cycle I. In cycle I, the mean score obtained was $37,37 \%$. This means that there was an increase but not significant. In the first cycle, the children began to be able to make a collage from sand, the children began to be able to draw using twigs. Because the increase was not significant, the researcher and collaborator proceeded to cycle II. In the cycle II, the mean score obtained was 94,96\%. This shows that in cycle II there is a significant increase. It can be seen from the observation instrument of the ability of naturalist intelligence that the children are already able to draw with twigs, create a collage with sand. Therefore, the provision of the act or the research stopped.

During the activity, the child shows an enthusiastic attitude towards the learning activities using natural materials. This is important for children so that children have an interest in such activities and also. Indicators used as reference in this study increased for a given action during 4 meetings in cycle I and 4 meetings in cycle II.

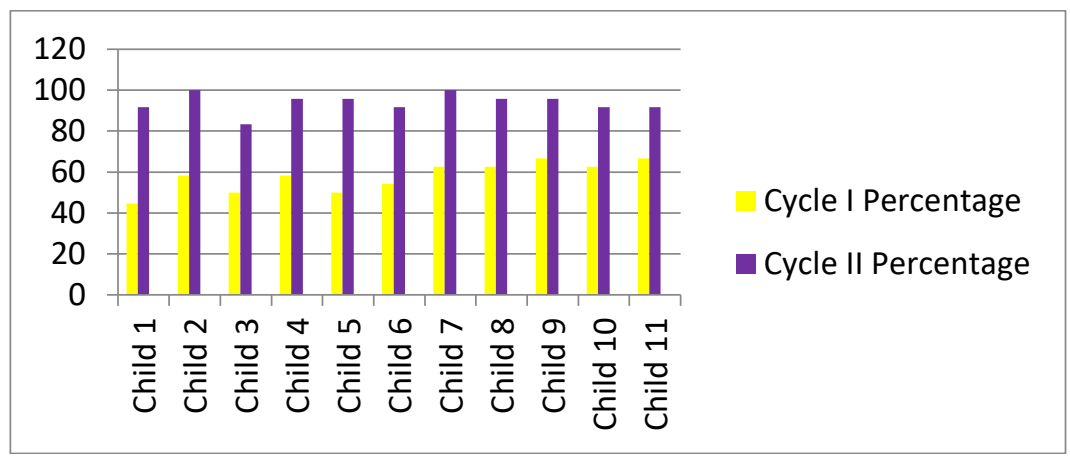

Fig. 2. The difference in cycle I and II 
All the indicators that have been mentioned one by one have increased after giving action at the end of cycle II. Learning activities using natural materials can enhance the children's ability of naturalist intelligence.

\section{CONCLUSION}

Based on the stages that have been done during the research, it was revealed that the average ability of children in the creativity of drawing on the cycle I was $57.57 \%$ and each child has not experienced the increase as expected. The mean score of naturalist intelligence in cycle II was $94,96 \%$ and increased by $18,19 \%$ of initial assessment before experiencing the action. From 11 children given the action, 10 children have improved their ability of naturalist intelligence through the use of natural materials.

\section{REFERENCES}

[1] Yuliani Sujiono, Konsep Dasar Pendidikan Anak Usia Dini. Jakarta; PT Indeks, 2008.

[2] Takdiratun Musfiroh, Cerdas Melalui Bermain (Cara Mengasah Multiple intelligence Pada Anak Sejak Usia Dini. PT. Grasindo, 2008.

[3] T. Armstrong, Setiap Anak Cerdas. Jakarta: PT Gramedia Pustaka Utama, 2002.

[4] C. . Miller, Nursing for wellnes in older adults, sixth edition. Philadelphia : Lipincott Williams \& Wilkins, 2012.

[5] "VISI PAUDNI," VISI PAUDNI, p. 25, 2013.

[6] Mary Renck Jalongo, Early Childhood Language Arts, 6th Edition. 2014

[7] Suharsimi Arikunto, Penelitian Tindakan Kelas. Jakarta: Bumi Aksara, 2018.

[8] P. 146, "Kurikulum 2013 Pendidikan Anak Usia Dini.” 2014. 